\title{
EXCLUDED SPACES IN FEMINIST FRONT IN INDIA - CURRENT SCENARIO
}

\author{
Aditi Korgaonkar a, Manisha Ghatage ${ }^{b}$ \\ a University of Mumbai, India \\ b SNDT Women's University, India \\ Corresponding email: korgaonkar.aditi@gmail.com
}

\begin{abstract}
"Many women did not fight against oppression because they did not realize they were oppressed in the first place" - Nora Ruck (2015)

Urban spaces in India are filled with slogans and shouts for sexual freedom, bodies and choices. Many celebrities are endorsing the concept of feminism through various social media. Is this medium inclusive of all of India's gender issues and gender realities? Is economic, political, religious and caste system which encompasses the social structure of India, taken into consideration while studying feminist issues? The unfortunate answer is not in affirmation. The lower caste women strongly believe that the feminist ideas are of, by and for the upper caste individuals. These ideas largely ignores the lower strata of the women's society, who are oppressed twice compared to the upper castes, first by the caste system and secondly by Patriarchy. Therefore, the lower caste women termed this activism as 'metropolitan feminism' and they believe that feminist movement which strongly speaks about sisterhood is yet to treat a lower caste woman as an equal sister. The research aims to study the field of feminism in the context of caste system in Indian society. The two main fields neglected by the field of psychology in India are caste systems and feminist psychology. Hierarchy of castes has always been an inevitable part of the social structure in India. While throwing light on these issues, the research also tries to focus on how feminism in India is circled around the upper caste women and hardly considers lower caste women. The study is in the lines of global feminism and emergence of black feminism. The paper calls to research this exclusion in the light of field of psychology.
\end{abstract}

Keywords: Feminism, Feminist Psychology, Dalit Feminism, Patriarchy.

\section{Introduction}

Since ion years, women are not free from patriarchal societal structures and are oppressed and also seen as the weaker gender. Even today, we can see the ceiling effect in the most developed countries as well. Both topics of this research paper experience dominance of patriarchy which hinders one's well-being. In India, where caste system is so much more prevalent in everyday lives, psychology research lacks inclusion of this topic. Another area which the subject fails to address is feminist psychology. Though feminist psychology emerged in the west during 1970s, yet it is not incorporated in the mainstream psychology studies in Indian universities.

This paper is organised into two main sections which addresses the exclusion of two fields under the broad topic, 'feminism in India'. Dalit feminism which emerged as a critique against mainstream feminism forms the structure of former part of this paper and is preceded by a topic known as feminist psychology which largely and widely remains untouched in Indian context. As a female researcher in psychology, I would like to study the dynamics of the same. The field of psychology have neglected the area of feminist psychology for a long time. The way patriarchy binds the caste system, in a similar way mainstream psychology formed its theories while considering male as a norm. Thus, we can consider these two topics under the broad topic of feminism. The only connection between both the 


\section{Asia Pacific Journal of Advanced Business and Social Studies \\ ISBN (eBook): 9780994365675 I ISSN : 2205-6033 \\ Year: 2017 , Volume: 3, Issue: 2}

topics is 'exclusion'. Exclusion of dalit women in mainstream feminism and exclusion of feminist perspective in psychology can

be observed while studying these areas. Though dalit feminism and feminist psychology do not share common goals and are different in their own way, the framework of both the topics is still based on a same criteria which is voice against patriarchy and marginalization.

\section{Dalit Feminism}

Before the Mughal and British rule, caste system was already prevalent in the predominated Hindu society in India. It started with stratification based on occupation, but over the period of time, it turned out to be so rigid that once born in a specific caste, the status and hierarchy of the individual couldn't be changed and the rights and privileges as a human reduced as the hierarchy of the caste in the system decreased. Thus, the low caste people were born generally known as 'dalits' in India. Irrespective of education, financial status, occupation and language, they still remain low caste in Indian society till the current date. There is a stark difference between caste and class and let the meaning of both the terms not get confused with each other. 'Class' can be defined as a system or order in the society which divides people into sets based on economic status. Whereas 'caste' is a social category to which an individual belongs involuntarily (by birth only). Caste system is a social stratification of the society offering no social mobility during the individual's lifetime. Unlike lower class, lower caste people cannot attain higher caste irrespective of their achievements in educational and economical status. These achievements will change their social class, but not their caste. Needless to say, this stratification was designed by men in the society and this hierarchy of castes considered all women equivalent to the low caste, irrespective of which caste they were born in. Oppression of low caste individuals and women is an age old phenomena in the Indian society.

Even today, the caste system dominates the Indian society. Many movements initiated by social reformers against the abolition of caste can be seen in the history of the Indian nation. But along with this, when feminism was taking shape in western countries, many revolutionaries started working towards upliftment of women in Indian society. But, unlike feminism in western countries, feminism in India was initiated by men and later joined by women. They advocated the term feminism which in simple words means, guarding equal rights for women as enjoyed to men. In India, feminist movements started with abolishing the practice of 'sati' and imparting formal education to women. The reformists at these fronts were Raja Ram Mohan Roy in Bengal and Mahatma Joytirao Phule in Maharashtra respectively. Mahatma Jyotirao Phule took a step by first educating his wife Savitribai Phule and then starting a school for girls, where Savitribai Phule was a teacher. Thus, India got her first female teacher. Tarabai Shinde was the first woman to write feminist texts. Pandita Ramabai criticized the caste system and patriarchy of the society and married outside the caste and also converted to Christianity.

In the nineteen century, when the western feminist activists focused the feminist movements on legal issues like gaining women's suffrage, feminism in India had a completely different scenario. The feminist movement was initiated by men and was focused on uprooting the social evil practice called as 'sati', allowing widow remarriage, abolishing child marriages and reducing illiteracy. Many upper caste women rejected the constraints they faced under Hindu traditions which were dominantly ruled by upper caste Brahmins.

Though the emergence of feminism in western countries and India was on a different note, the gist of the struggle was in the same direction which implied equality of rights and no discrimination based on gender. After the independence, feminism in India somewhat replicated western feminism. The ideas of the movement were similar to that of the western countries. India got her first woman Prime-Minister, Indira Gandhi in 1966 who is the only child of India's first Prime-Minister and freedom fighter, Jawaharlal Nehru. Literacy rate 


\section{Asia Pacific Journal of Advanced Business and Social Studies \\ ISBN (eBook): 9780994365675 I ISSN : 2205-6033 \\ Year: 2017 , Volume: 3, Issue: 2}

and working class saw a rise in women's population. But, these advancements are only amongst a minuscule of population in India. And it only remains on paper, as even today there are many issues which inhibit women from taking full advantage of new rights and opportunities in India.

India largely being a patriarchal society, the maximum number of households has fathers or husbands as their official heads. Women aren't aware of their rights because of lack of exposure. Families don't mind investing funds for son's education, but hesitate to do so when it comes to their daughters. Female infanticide is still practised in many parts of the countries though it is against the law. Even at political level, parties do not seek to support female candidates and think as waste of resources against male candidates. Though women in India have a right to vote, to a greater extent it doesn't hold any good because they have a low level of political awareness and aren't encouraged to pose awareness about the issues. Irrespective of the class, on a wide scale, women are held responsible and worthless if they aren't able to produce male child. They have to face the stigma and abuse in the society. These are few of the examples which the women are facing in Indian society. Many women activists in collaboration with NGOs are striving towards a better life for Indian women. Many campaigns are held by women to protect their rights in the country. But, there are some criticisms from the low caste (Dalit) groups that feminism is meant for upper caste and upper class Hindu women and they marginalise and ignore the interest of Dalit women. As such, a new concept known as 'Dalit Feminism' has been created. "Mainstream feminism lacks the awareness on the dalit grassroots level experiences and dalit patriarchy", says Rege (1998).

\section{Analogy of Black Feminism}

While studying Dalit feminism, we can see many similarities and connections with Black feminism. As Black feminism is to western countries, Dalit feminism is to India. Both have dynamics of upper-caste women and US white women while they marginalise Dalit women and Black women respectively. Women in women's movement lack understanding of feminism. Feminism opposes all kinds of injustices and inequalities. But mainstream feminist do not oppose or resist caste in India (Kumar, 2008). If we see the data, poor working class women, adivasi women, women agricultural labourer and dalit women attend meetings on a large scale of women's movement, but they are just followers. They aren't given any roles of responsibility or leadership under the pretext of poor education or awareness. There are so many connections between dalit and black women. Black women do not have role of responsibility in the mainstream women's movement.

There are two different special voices shouting in the wilderness for liberation-the Dalit woman in India and the Black woman in America who are under the triple-subjugation of caste or race, gender and class (Rose, 2014). Faustina Mary uses her pen as a powerful source to criticise and fight against mainstream feminism. She is a Tamil Dalit women writer and her pen name is Bama. She is powerful and challenging voice of dalit feminism. She charges directly on the issues related to untouchability and patriarchy. While critiquing mainstream feminism and distinguishing dalit feminism from it, Bama,(2007) says, "All women in the world are second-class citizens and Dalit women experience a total lack of social status; they are not even considered dignified human beings. Hard labour and agony are their lot in life. Other problems are the same for all women". In her essay "Dalit Women: Problems and Prospects" Bama writes, "Since our society is not only a male-dominated society, but upper-caste male-dominated society, a Dalit woman's problems are unique, she is a Dalit among Dalits" (Barnett \& Hyde, 2001). Dalit feminists strongly believe that Indian feminism excludes dalit women. They feel that dalit women are twice cursed, first as women and then being dalits. Dalit women feel that they are oppressed more as a women and being dalit by upper caste men and men of their caste as well. The lower caste women strongly 


\section{Asia Pacific Journal of Advanced Business and Social Studies \\ ISBN (eBook): 9780994365675 I ISSN : 2205-6033 \\ Year: 2017 , Volume: 3, Issue: 2}

assert that the feminist ideas are of, by and for the upper caste individuals. Therefore the lower caste women termed this activism as 'metropolitan feminism' and they believe that feminist movement which strongly speaks about sisterhood is yet to treat a lower caste woman as an equal sister.

The Dalit women are positioned at the bottom of both India's caste and gender hierarchies. They experience endemic gender and caste discrimination and violence as the outcome of severely imbalanced social, economic and political power equations and their socioeconomic vulnerability combined with double risk factors of being Dalit and woman, increase their exposure to potentially violent situations, while simultaneously reducing their ability to escape says, Somali Saha (2017) in her paper, "Chronicling the History of Dalit Consciousness: An Analysis of Urmila Pawar'sThe Weave of My Life- A Dalit Woman's Memoir".

\section{Current Scenario in India}

If we focus on contemporary society and women's life in India, we will reach a point of debate whether or not we as a society are aware about feminism and its principles. Though it is wide spread in the country, we have yet to reach in remote rural areas of the country. Metropolitan feminism which a term used by dalit feminists say that the feminist movement which talks about sisterhood, haven't yet treated a lower caste woman as an equal sister. The issues and problems of lower caste women remain untouched and are ignored in both rural and urban India.

Feminism in India conveniently ignored the factors of caste and class, which are very important in a society like India. Mainstream feminists could not deny the fact that being women of an upper caste, they enjoy the privileges of their caste and a respectable caste position in the society, where as dalit women face caste discrimination. Such caste oppression and the discrimination that dalit women face are not exclusively from upper caste Hindu men, but from upper caste Hindu women as well.Rural or urban have its own understanding and practices of feminism. Water bodies in rural India are highly under control of upper castes. Upper castes women deny access to these sources under the assumption of pollution and purity which clearly shows and maintains caste discrimination. There was a case in rural north India where a dalit girl gets beaten up by upper caste women after her shadow falls on upper caste man of the same family (The Indian Express, 2015). Urban areas where lower caste women are generally involved in menial jobs, they are not allowed to enter the kitchen and worship places. If there is an incidence, where lower caste, economically affluent family want to employ labour for jobs like household chores, driving, etc, poor class but upper caste denies to work under them. Even educated people in offices both government and private, try to find the caste of co-employee by asking their family names which decides their future friendship or to maintain distance. Unfortunately, family names in India indicate the person's caste. Thus, person's caste is considered an important identity to create and maintain relations. In the cases of rape and violence, dalit women have very limited access towards justice. Thus, they become very easy targets for sexual violence because the perpetrators easily get away with the crime. Police often deny or neglect dalit women's legal or judicial rights. Majority of cases of violence against dalit women are not registered. They are also unaware about the laws and their ignorance is exploited by their opponents, police and judiciary systems. Apart from caste and discrimination, they also have major obstacles in acquiring basic services of health care, education, water and sanitation. Dalit women are key targets of trafficking. 98\% of them are involved into dehumanising work of removing human waste by hand and manual scavenging.

Many dalit feminist through their writings and work are trying to reach the masses and create an awareness related to the same. In this context, work of eminent people in this field like Gopal Guru, Baby Kamble, Sharmila Rege, Bama and Urmila Pawar to name a few 


\section{Asia Pacific Journal of Advanced Business and Social Studies \\ ISBN (eBook): 9780994365675 | ISSN : 2205-6033 \\ Year: 2017 , Volume: 3, Issue: 2}

cannot be ignored. The pioneer in this social reform movements are Mahatma Jyotirao Phule and Dr. Ambedkar. Their work reflects the conditions of dalit women and they voice against the patriarchy and upper caste feminism. But still, the campaigns and activism do not change the

current situations and restore the dignity of lower caste women. As truly said by Ruck, (2015), "Many women did not fight against oppression because they did not realize they were oppressed in the first place" There is lack of awareness amongst lower caste women to fight against this oppression. They are dealing with these issues in their everyday lives in their own ways. Though education plays an important role in awareness, it need not be the sole reason behind it. Self-awareness is the most integral part in understanding feminism and its practices.

Throughout history, dalit women have been active but often they are not recorded. Since 1920 s, they have been active in anti-caste and anti-untouchability movements. They are making mark as an independent thinkers and writers in the literary world; however, they are unable to put an end to the exclusion and structural discrimination. Violence is used by higher caste to keep them in place and therefore the revolution is unable to take a formal shape.

The National Federation of Dalit Women (NFDW) was launched by dalit women themselves to bring positive changes in their lives by taking legal actions against caste based atrocities and to build self confidence and leadership qualities. A feminist NGO based in Gujurat named Anandi, works on empowering women in economic, social and political awareness and mobilization. In Uttar Pradesh, north India, Dalit Mahila Samiti is an organization for a movement of dalit women.

After almost 70 years of independence, dalit women in India still work under the unorganised, unskilled sector. This is majorly due to lack of education and economic constraints. In cities, they work as hawkers, house maids, scrap collectors and in rural parts they mostly work as agricultural labourers, bonded labourers, etc. Though dalit men themselves are prey of indiscrimination and caste, they do not support dalit women and at homes follow the upper caste systems of patriarchy. Many a times, dalit women face violence and abuse at young ages and are forced into prostitution and the flesh market. This can be still seen both in cities and rural areas.

There are many NGOs and other organizations fighting for the rights of dalit women. They also try to educate them and teach basic survival skills. But these programs do not get much success compared to the overall population of dalit women in the country. There is a need of the government to engage in such initiatives to reach huge masses in the interior areas of the countries as well.

\section{Feminist Psychology}

In 1960 s, there was an argument at the feminist front that the field of psychology has been neglecting the study of women and gender and misinterpret women in its research and theories. The period of great feminist activism gave rise to an influential and new area of research on gender and women. The third wave of feminism acted as a catalyst in this research area pertaining to women in the field of psychology and issues related to the same. Thus, conceiving a new area in interest of women's rights and equality in the field of psychology called, 'feminist psychology'.

Feminist Psychology is centred on social structure of the society and gender. It openly critiques the historical psychological research which is mainly based on male perspective. It is against the view that considers males as a norm.

In 1972, Edith Greenglass stated that field of psychology is male dominated. Women were totally excluded. Use of word 'woman' in conjunction with psychology was forbidden. 


\section{Asia Pacific Journal of Advanced Business and Social Studies \\ ISBN (eBook): 9780994365675 I ISSN : 2205-6033 \\ Year: 2017 , Volume: 3, Issue: 2}

In 1970s, feminist psychology emerged as a distinct field of research and practice. The core principle of feminist psychology was explicit commitment to using psychology to understand and improve the lives of women and girls of all ages, ethnicity, sexual orientation, abilities and socio economic status.

Feminist psychology is based on principles of feminism. It puts strong emphasis on women's rights. The revolution was a grassroots one thus; it is difficult to name the originator. But the

term was originally coined by Karen Horney. She strongly believed that feminine traits were largely neglected in mainstream traditional psychology. Most of her work focused on psychology from the women's perspective and in the interest of women. She also spoke about 'womb envy', a trait in men where they are envious about women's ability to bear children, which was in context to Freudian phenomenon of 'penis envy'- a very masculine way of portraying women and her envies. Pioneering the field of feminist psychology, she had an urge to prove that all over the world, cultures and societies encourage women to be dependent on men for their love, care, wealth and protection. She constantly stressed that self-awareness is a part of being stronger, better and rich human being.

As already stated above, third wave of feminism led to focussing on feminist psychology. The core argument of feminist psychologists was psychology failed to study women and gender and produced biased science. Feminist psychologists argued that the neglect of women and gender had produced largely "womanless" knowledge (Crawford \&Marecek, 1989), and that sexism plagued much of the theory and research that had been produced (McHugh, Koeske, \& Frieze, 1986; Sherif, 1979).

All the therapeutic approaches are majorly given by male psychologists. When men are used as norms, stereotypically masculine gender roles are considered as standard. As a result, behaviour deviating from these norms, i.e., feminine behaviour is likely to be identified as pathological. A Similar trend is observed in therapeutic intervention. Therapeutic process is male dominated, male centred and male controlled.

Shields (1975) questioned the 'social myth' about maternal instinct that traditional psychologists had created. A realization of merely being a good wife and mother to children, women can be scientists had taken birth. But the irony was women over $\mathrm{n}$ number of years were conditioned to depend on men; right from basic needs to self-esteem that it became difficult to inculcate the thought of feminism and equality on their primed minds. In Weisstein's, (1968) words, "One must understand the social conditions under which women live if one is going to attempt to explain the behaviour of women. And to understand the social conditions under which women live, one must be cognizant of the social expectations about women." The critiques of traditional therapies urged to fill in the missing science and to develop theories and methods that would be free of the biases.

Feminist psychologists points out few issues with traditional therapies in psychology. According to them, there are gender biases, as the traditional therapies expect female clients to be expressive, submissive and nurturant and for good mental health, they should follow their sex roles. Andocentrism is another issue which feminist psychologists point out. As the traditional therapies are formed by considering male as a norm which is set as a standard, any behaviour deviating from this standard is seen as deficiency. Male traits are seen as highly valued in the society. Without taking into consideration women's actual experiences and living conditions, men write theories on female development. This is highly criticised by feminist psychologists. By focussing on internal functioning instead of socio-political influences, traditional therapists tend to blame the client for their symptoms. These intrapsychic assumptions are often questioned by feminist psychologists. 


\section{Asia Pacific Journal of Advanced Business and Social Studies \\ ISBN (eBook): 9780994365675 | ISSN : 2205-6033 \\ Year: 2017, Volume: 3, Issue: 2}

\section{Perspective of Feminist Psychology}

Feminist psychologists see psychology as sexist, patriarchal, value laden and andocentric. According to them, psychology has masculinist bias which means contributions made by men to psychology are more important than those made by women. History of psychology is history of male psychology which takes male as norm to compare and judge women and it decides what is worth investigating about women.

Feminist critiques view role of feminism in psychology as purely political and do not see feminist psychology as legitimate science. According to them, feminist psychology has very little impact on mainstream psychology.

Feminist psychologists generally maintain that research should contribute to social action and social justice as well as to knowledge (Riger, 1992). From this perspective, the discipline of psychology would potentially transform society to produce gender equality (Kahn \& Yoder, 1989).

\section{Current Research}

Current research in the field of feminist psychology mainly pertains to violence relationalcultural theory, emotion and leadership. Feminist psychologists are trying to empower and develop techniques to lessen the gender inequality and masculinity bias and develop an equality based therapies to resolve the issue in the field of mental health. They are striving to incorporate and apply these techniques in the psychological therapies. The core issues of these therapies are rape, domestic violence and career counselling.

There is a rise in conception of feminist psychology organizations. Western countries have formed subgroups in psychological associations which are based on feminist psychology viz, Society for the Psychology of Women (SPW) is a subdivision in American Psychological Association, Psychology of Women Section (POWS) of the British Psychological Society (BPS) was created. A Section on Women and Psychology (SWAP) is a part of the Canadian Psychological Association (CPA). Alexandra Rutherford founded Psychology's Feminist Voices (PFV) which is an online teaching resource.

Feminist therapists work with females as well as males in search of counselling. How multiple social identities can impact an individual's functioning and gender are their main areas of interest. Psychologists or therapist irrespective to which gender they belong can call themselves feminist therapist if they believe in gender equality and feminist psychological theory. The therapies are modelled around gender-fair counselling techniques.

\section{Current Scenario in India}

Feminist psychology is an indispensible part of feminism. The question here arises, what is the current scenario in the Indian society? Are we aware of feminist psychology and feminist therapies? In a broader view the answer is not affirmative.

Patriarchy creates inequality. Indian society being patriarchal in nature, it is very difficult to include feminism or feminist psychology in the mainstream educational system. There is dominance of male centered content and language in the education systems. Feminist scholars argue that classrooms are not neutral sites of production and reproduction of knowledge (Rakow, 1992). In our families and society, it is taught to both the genders that male members possess greater quality of being rational and thus, they inherit the role of decision makers. Thus, patriarchal education system conditioned women to think the other sex superior to them. There is similarity of this pattern in family and society as well. 


\section{Conclusions}

As a researcher in social psychology, I feel that to reach the awareness to the masses, we need to incorporate the ideas of dalit feminism, awareness of caste system, indiscrimination, in the minds of the people. Educating and creating awareness can only lead to abolition of caste. Government and mainstream feminist do create organizations for women rights and freedom, but it is not reaching to the roots of the society. In governmental forms, still caste has a space to be filled. Family names/surnames still indicate one's caste. When will these indicators of discrimination and racism cease their function?

On the psychology front, universities are still using age old syllabus of traditional therapies. Psychology as a subject fail to address caste and feminist theories when it in context of Indian society. How can a counselling session take place without understanding the social, political stand of an individual? Indian universities are still using therapies which are constructed with reference to different culture commonly, western. To understand an individual here, doesn't it require a change in socio-cultural aspects? Incorporating the ideas of feminist psychology in the minds of the people will still take few years. Men and women advocating feminist psychology have a greater and important role in making the masses understand the need of the hour in order to attain a better mental health in the society. 


\section{References}

i. $\quad$ Barnett, R. \& Hyde, J., 2001. Women, men, work and family: An expansionist Theory. American Psychologist, 56(10), p. 781.

ii. $\quad$ Crawford, M. \& Marecek, J., 1989. Feminist theory, feminist psychology. Psychology of Women Quarterly, 13(4), pp. 477-491.

iii. Eagly, A. et al., 2012. Feminism and psychology: analysis of a half-century of research on women and gender.. American Psychologist, 67(3), p. 211.

iv. Fine, M., 1985. Reflections on a feminist psychology of women: Paradoxes and Prospects. Psychology of Women Quarterly, 9(2), pp. 167-183.

v. Forrest, L. \& Rosenberg, F., 1997. A review of the feminist pedagogy literature: The neglected child of feminist psychology. Applied and Preventive Psychology, 6(4), pp. 179-192.

vi. Guru, G., 1995. Dalit women talk differently. Economic and Political Weekly, pp. 2548-2550.

vii. $\quad$ Kumar, R., 1989. Contemporary Indian Feminism. Feminist Review, Volume 33, pp. 20-29.

viii. Rege, S., 1998. Dalit women talk differently: A critique of' difference and towards a Dalit feminist standpoint position. Economic and Political Weekly , pp. 39-46.

ix. $\quad$ Rege, S., 2006. Writing caste, writing gender: reading Dalit women's testimonios, s.l.: Zubaan.

x. $\quad$ Rose, L., 2014. Indian Subaltern Feminism and American Black Womanism.In Proceedings of International Academic Conferences (No. O100872).. s.l., International Institute of Social and Economic Sciences.

xi. Shields, S., 2008. Gender: An inter sectionality perspective. Sex Roles , 59(5), pp. 301-311.

xii. $\quad$ Westkott, M., 1986. The feminist legacy of Karen Horney. s.l.:Yale University Press. 